KENOSIS : JURNAL KAJIAN TEOLOGI

ISSN 2460-6901(Print), 2656-4483 (Online)

https://e-journal.iaknambon.ac.id/index.php/KNS

DOI: $10.37196 /$ kenosis.v7i2.352

\title{
NAOMI MENGELUH ATAU MENGGUGAT ALLAH ATAS PERISTIWA KEHILANGAN?: \\ Suatu Tafsiran Terhadap Narasi Rut 1:1-22
}

\section{Vani Mega Rianna Mantong Tendenan}

\author{
Sekolah Tinggi Filsafat Theologi Jakarta \\ Jl. Proklamasi No.27, RT.11/RW.2, Pegangsaan, \\ Kec. Menteng, Kota Jakarta Pusat, DKI Jakarta 10320 \\ vanimantong@gmail.com
}

\begin{abstract}
Naomi experiences the loss of her husband and two children are the opening narrative of the book of Ruth. Naomi's loss becomes an experience of faith that drives the narrative of the book of Ruth. This paper aims to eliminate the loss in the perspective of the book of Ruth specifically based on Ruth 1:1-22 by using the exegesis method that pays attention to the context, genre, and content of the text. The stages carried out are the first to explain the exegesis method, namely narrative, the second is to describe the context, the third is to analyze the genre of the book of Ruth, and the fourth is to analyze the words wattissaer, noomi, and mara. Then fifth notice the text of Ruth 1:1-22. Based on the research results on the text of Ruth 1:122 , the authors found the word wattissaer as an indication of the cause of the emergence of the name game from Naomi from the word noomi to mara. The historical context, authorship and theological context of the book of Ruth show the loss of Naomi as part of the experience of faith to see God's role in it. Wordplay becomes possible in the book of Ruth because its genre as a story or narrative also supports the narrator in doing so. The author sees the loss experienced by Naomi as not an ordinary loss but a loss that can be understood as part of God's test of Naomi's faith, which then changes Naomi's name to respond to complaints to God but not to suing God.
\end{abstract}

Keywords: Exegesis, lost, mara, Naomi, Noomi, Wattissaer

\begin{abstract}
Abstrak
Naomi mengalami peristiwa kehilangan suami serta kedua anaknya yang merupakan narasi pembuka Kitab Rut. Kehilangan yang dialami Naomi menjadi pengalaman iman yang menggerakkan narasi Kitab Rut. Tulisan ini bertujuan untuk mengkaji
\end{abstract}


kehilangan dalam perspektif kitab Rut secara khusus berdasar pada Rut 1:1-22 dengan menggunakan metode eksegesis yang memperhatikan konteks, genre, dan isi teks. Adapun tahap-tahap yang dilakukan ialah pertama penjelasan metode eksegesis yaitu naratif, kedua penjabaran konteks, ketiga menganalisis genre dari kitab Rut, keempat analisa terhadap kata wattissaer, noomi, dan mara. Kemudian kelima menafsirkan teks Rut 1:1-22. Berdasarkan pada hasil penelitian terhadap teks Rut 1:1-22, penulis menemukan kata wattissaer sebagai indikasi penyebab munculnya permainan nama dari Naomi dari kata noomi menjadi mara. Konteks sejarah, kepenulisan dan konteks teologis kitab Rut menunjukkan peristiwa kehilangan Naomi sebagai bagian dari pengalaman iman untuk melihat peran Allah di dalamnya. Permainan kata menjadi sangat mungkin dalam kitab Rut karena genrenya sebagai cerita atau narasi juga mendukung narator dalam melakukannya. Penulis melihat kehilangan yang dialami Naomi bukanlah kehilangan biasa melainkan kehilangan yang dapat dipahami sebagai bagian dari ujian Allah terhadap iman Naomi yang kemudian perubahan nama Naomi menjadi respons keluhan kepada Allah tetapi bukan menggugat Allah.

Kata kunci : eksegesis, kehilangan, mara, naomi, Noomi, Wattissaer

\section{PENDAHULUAN}

Berbagai peristiwa kehilangan belakangan ini menjadi realitas yang menguat di masa pandemi. Tidak sedikit orang yang kehilangan pekerjaan, kehilangan mata pencaharian, kehilangan keluarga, kehilangan nyawa. Bagaimana merespons kehilangan sebagai peristiwa realitas kehidupan yang tidak bisa dihindari? Apakah individu pantas mengeluh kepada Allah atas kehilangan yang dialami?

Kitab suci dalam hal ini Perjanjian Lama mencatatkan peristiwa kehilangan yang direspons dengan mengeluh, menggugat dan mempertanyakan Allah sebagai bentuk pengakuan Allah di tengah penderitaan. Secara khusus dalam kitab Rut 1:1-22 yang menggambarkan dinamika kehilangan dari Rut dan Naomi. Jika dipahami secara harfiah teks ini hanya menunjukkan kesetiaan Rut terhadap mertuanya Naomi yang mendominasi dibandingkan dengan peristiwa kehilangan yang dialami oleh Naomi. Akan tetapi, terdapat konsekuensi etis-teologis dibalik kisah Rut dan Naomi bahwa Allah tampaknya sengaja untuk membuat Naomi mengalami peristiwa kehilangan.

Berdasarkan pada situasi di atas, penulis akan mengkaji kisah Naomi dalam Rut 1:1-22. Apakah teks tersebut berbicara tentang kehilangan dan respons Naomi terhadap kehilangan ialah menggugat Allah? Ataukah ada maksud lain yang ingin ditonjolkan oleh penulis kitab Rut melalui peristiwa yang dialami Naomi? Cara merespons kehilangan menjadi masalah penting karena beberapa peristiwa kehilangan 
belakangan ini menjadi peristiwa tragis yang memungkinkan setiap orang untuk menjadi apatis terhadap kehadiran Allah, atau justru sebaliknya bersikap menerima tanpa memaknai kehadiran Allah di dalamnya. Melalui artikel ini penulis berharap dapat memberikan sumbangsih teologis dalam merespons kehilangan sebagai peristiwa kehidupan manusia.

Pada teks Rut 1:1-22 terdapat kata kehilangan (wattissaer) yang merupakan bagian pembukaan kisah dari Naomi dan Rut sebagai dasar konteks bagi kelanjutan kisah kelangsungan hidup Naomi dan Rut. Lalu respons yang ditunjukkan Naomi terhadap kehilangan yang dialami terdapat dalam Rut 1:20-21 digunakan dengan permainan kata pada perubahan nama Naomi menjadi Mara. Penulis melihat respons Naomi sebagai bentuk keluhan terhadap Allah yang menguji imannya melalui peristiwa kehilangan. Dalam hal ini penulis akan mengkaji peristiwa kehilangan dan respons terhadapnya melalui beberapa bagian sub topik. Pertama, pemaparan mengenai metode yang digunakan penulis ialah metode eksegesis. Kedua, analisis konteks penulisan kitab Rut untuk dapat menemukan makna teks. Ketiga memaparkan karakteristik atau genre kitab Rut 1:1-22. Keempat, analisa kata wattissaer, noomi, dan mara. Kelima menafsirkan Rut 1:1-22 dan yang kelima ialah kesimpulan.

\section{METODE PENELITIAN}

Tulisan ini mengarah pada metode kualitatif dengan pendekatan deskripsi analitis dan studi literatur. Dalam melakukan penafsiran, penulis menggunakan metode eksegesis yaitu naratif untuk menemukan makna atau maksud penulis kitab Rut. Bagi Stuart, eksegesis adalah upaya untuk menemukan apa maksud teks itu, bukan apa artinya sekarang. ${ }^{1}$ Pada bagian ini, Stuart memperjelas tugas dari eksegesis sebagai metode dalam menemukan makna teks bahwa yang utama eksegesis ialah upaya menggali makna teks, pada dasarnya objektivitas menjadi yang utama dalam melakukan eksegesis. Metode ini digunakan penulis untuk menggali dan menemukan maksud penulis kitab Rut secara khusus pada pasal 1:1-22. Sebagaimana masalah yang diungkapkan bahwa teks ini didominasi dengan pandangan akan kesetiaan Rut sehingga tampaknya peran Naomi dalam teks ini menjadi kabur atau tidak bermakna dalam penulisan kitab Rut, karena itu melalui metode ini pembaca dapat menggali keaslian teks dari kitab Rut. 


\section{HASIL DAN PEMBAHASAN}

\section{Konteks Kitab Rut}

Kitab Rut menjadi kitab yang menarik karena menggunakan nama perempuan selain kitab Ester dan termasuk dalam kitab yang singkat, terdiri dari empat pasal. Kemungkinan kitab Rut dalam tradisi Masoret termasuk dalam kitab Hikmat, berada dalam satu grup dengan kitab-kitab yaitu Kidung Agung, Pengkhotbah, Ratapan dan Ester yang subjeknya berhubungan dengan gender feminin. ${ }^{2}$ Tidak dapat dipungkiri bahwa kitab Rut sebagai salah satu kitab yang menonjolkan gender feminin kemudian menggunakan tokoh Rut dan Naomi untuk menggambarkan keterwakilan perempuan di dalam Alkitab. Menarik bahwa penggambaran tokoh perempuan ini dibingkai dalam nuansa sejarah Israel yang juga ingin menunjukkan sejarah keselamatan Allah atas Israel melalui penokohan kitab Rut.

Kisah Rut menceritakan sejumlah peristiwa yang terjadi pada zaman hakimhakim, sekitar 200 tahun sebelum Daud menjadi raja Israel sehingga beberapa istilah dan adat istiadat orang Ibrani berasal dari zaman ini. ${ }^{3}$ Kitab Rut dimulai dengan informasi tentang Israel pada masa hakim-hakim (1:1), penyebutan ini menunjukkan sejarah bangsa Israel dalam masa gejolak secara rohani maupun politik. ${ }^{4}$ Penggambaran zaman para hakim dalam pembukaan teks kitab Rut menunjukkan secara eksplisit bahwa sedang terjadi pergolakan pada masa itu, termasuk persoalan kelaparan yang terjadi di Israel yaitu di Betlehem-Yehuda. Namun masalah kelaparan yang digambarkan pada sisi yang lain menunjukkan sebuah bencana bagi Betlehem untuk memanggil umat kembali dalam pertobatan kepada Allah. Betlehem artinya "rumah Roti", kelaparan itu mengerikan sampai-sampai di "rumah roti” sekalipun tidak ada lagi roti. ${ }^{5}$ Penulis kitab Rut menempatkan persoalan kelaparan sebagai masalah yang tidak dapat menemukan solusinya sehingga tidak ada cara lain untuk mengatasi kelaparan selain mengungsi. Mengenai penulis kitab Rut, hingga saat ini tidak ada kesimpulan jelas siapa penulisnya. Ada asumsi bahwa sebagian besar kitab Rut adalah produk dari seorang penulis tunggal, dari tradisi Talmud mengaitkan kepenulisan Rut dengan nabi Samuel. ${ }^{6}$ Tidak ada konsensus yang pasti dalam memutuskan dugaan-dugaan terkait dengan penulis kitab Rut, dugaan mengarah pada penulis sebagi seorang terpelajar, mengetahui bahasa Ibrani, dan tampaknya akrab dengan tradisi Israel kuno. 
Ketika melihat konteks Rut dalam keterkaitannya dengan konteks kitab Hakim maka pembaca dapat menemukan implikasi teologis yang berbeda dan yang khas. Bagi James McKeown kitab Rut menampilkan pengalaman iman dari setiap penokohan untuk menunjukkan bagaimana iman kepada Tuhan menopang orangorang dalam keadaan sulit, beriman yang otentik. ${ }^{7}$ Berbeda dengan penggambaran tokoh-tokoh yang ada di kitab Hakim yang mayoritas ditampilkan dalam konteks kepemimpinan untuk menyadarkan bangsa Israel. McKeown mengutamakan peran para tokoh kitab Rut dalam menemukan makna teologis dari kitab Rut itu sendiri, yaitu tentang iman yang otentik ialah iman yang mampu bertahan sekalipun dalam masa sulit.

Bruce K. Waltke dari sisi yang lain melihat adanya atribut I AM's dalam kitab Rut yang menunjukkan tentang kasih yang tidak pernah gagal dan dilihat dalam hubungan munculnya pemimpin terbesar Israel yaitu Daud. ${ }^{8}$ Waltke secara implisit lebih menekankan peran Tuhan yang dominan dalam kitab Rut juga untuk merujuk kepada akhir kisah dari kitab Rut yaitu lahirnya keturunan Daud. Secara logis kitab Rut ingin menunjukkan wacana teologis tentang peran Allah dalam penderitaan, sebuah tawaran dalam memahami bahwa Allah dapat menggunakan siapapun untuk menolong termasuk melalui keberadaan orang asing yang ditekankan kitab Rut melalui kehadiran Rut bagi Naomi di Betlehem. Peran Allah ini menjadi sejalan dengan keselamatan yang ingin Allah tunjukkan bagi bangsa Israel yaitu lahirnya nenek moyang Daud yang berasal dari orang asing yang datang dari Moab. Tanpa kedatangan Naomi ke Moab mungkin cerita akan menjadi berubah dan nenek moyang Daud tidak datang dari orang asing. Keterkaitan antara pengalaman iman dalam penderitaan dan peran Allah di dalamnya menjadi kesatuan teologis yang khas dalam kitab Rut.

\section{Genre}

Analisa terhadap genre dari sebuah teks penting untuk dapat menemukan makna serta orientasi teks. Bagi Carol A. Newsom genre adalah mode persepsi yang mengkonseptualkan aspek realitas dengan cara yang berbeda, sebagai sarana untuk memahami realitas. ${ }^{9}$ Genre dari teks membentuk penulis dengan pembaca dalam menemukan realitas teks. Jeremy Schipper kemudian melihat bahwa seseorang juga 
dapat menganalisis penggunaan berbagai genre bergantung pada kebutuhan komunikatif pada titik tertentu dalam cerita. ${ }^{10}$ Schipper tampaknya tidak ingin memusatkan satu genre tertentu dalam memahami kitab Rut, sebaliknya Schipper melihat penggunaan berbagai genre dalam kitab Rut sebagai upaya keragaman komunikasi dalam menerjemahkan dan menginterpretasi teks.

Kitab Rut menampilkan sejumlah peristiwa yang menguatkan genre dari kitab Rut sebagai sebuah cerita. Alicia Ostriker melihat kitab Rut memiliki elemen cerita rakyat, disusun dengan seni yang membuat setiap kata berarti dan bergema,struktur yang seimbang, dialog yang fasih dan elegan, permainan kata, kiasan yang mentransformasikan maknanya. ${ }^{11}$ Ostriker menggambarkan fungsi dari genre kitab Rut sebagai cerita rakyat bahwa permainan cerita dalam kitab Rut menghidupkan setiap kata, dialog dan kaya akan makna karena cerita itu dibingkai dalam seni sastra. Tidak salah kemudian jika gambaran umum yang diperoleh sesudah membaca kitab Rut mulai dari pasal 1-4 ialah narasi dalam alur yang berkesinambungan.

Dalam KBBI cerita merupakan tuturan yang membentangkan bagaimana terjadinya hal (peristiwa, kejadian) atau karangan yang menuturkan perbuatan, pengalaman, atau penderitaan orang. ${ }^{12}$ Terlepas dari bagaimana penulis kitab Rut membuat alur narasinya akan tetapi melalui penggambaran suasana, tokoh utama, setting tempat, prolog hingga epilognya sangat tampak ciri khas dari kitab Rut yaitu sebagai cerita. Tod Linafelt membaca kitab Rut sebagai kitab yang hampir seluruhnya berbentuk narasi prosa itu bergeser ke dalam puisi, yaitu baris-baris syair yang ditandai secara formal. ${ }^{13}$ Linafelt melihat bentuk dari kitab Rut sebagai puisi, secara khusus dengan menunjuk ungkapan-ungkapan yang secara tidak langsung menampilkan bentuk dari syair yaitu Rut 1:16-17 dan 1:20-21. Kitab Rut bergeser ke mode puitis untuk memberikan akses pembaca ke kehidupan batin Rut dan Naomi, pergeseran ini mengedepankan pentingnya Rut dan Naomi dalam kitab Rut. ${ }^{14}$ Genre puisi yang ditawarkan oleh Linafelt memberikan penekanan lebih pada ungkapan atau dialog yang disampaikan tokoh utama yaitu Rut dan Naomi, namun tidak menghilangkan dimensi narasi dari keseluruhan kitab Rut. 


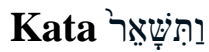

Pada Perjanjian Lama versi TB kata shaar muncul dalam 133 ayat yang juga penekanannya bergantung dari masing-masing konteks. Secara etimologis kata wattissaer dalam ayat 3 dan 5 berasal dari kata dasar shaar yang merupakan kata kerja. Kata shaar secara harfiah berarti to remain atau be left over. Namun penggunaan arti kata shaar dalam kitab Rut ini memiliki terjemahan yang berbedabeda. Alkitab terjemahan baru menuliskan kata wattissaer sebagai tertinggal dalam Rut 1:3 sedangkan pada ayat 5 diartikan sebagai kehilangan. Penggunaan kata yang sama namun memiliki terjemahan yang berbeda dalam TB menunjukkan kesinambungan atau sebenarnya mengarah pada sesuatu hal yang sama yaitu keadaan ditinggalkan.

Dalam versi NIV dan KJV kata shaar diartikan sama baik pada ayat 3 dan 5 sebagai was left. Bentuk pasif tunggal feminin dari kata kerja "meninggalkan" pada ayat 5 mengacu pada Naomi, tetapi tidak memiliki subjek yang dinyatakan secara independen. ${ }^{15}$ Dalam hal ini penulis sebagai narator kitab Rut tampaknya ingin menggunakan tokoh Naomi sebagai objek dari keadaan yang ditinggalkan sehingga yang meninggalkan Naomi sebagai subjek hanya sebagai pelengkap, tidak diberi penekanan utama karena penulis lebih merujuk kekhususan kepada tokoh Naomi. Naomi ditinggalkan sendirian, kehilangan anak dan menjadi janda. ${ }^{16}$ Munculnya kata shaar dalam Rut 1 dengan jelas mengarah pada keadaan, situasi ditinggalkan oleh suami dan anak sebagai peristiwa kehilangan yang dialami Naomi.

\section{Kata נָּרָא}

Kata noomi dalam Rut merujuk kepada nama dari mertua Rut. Kata noomi sendiri berasal dari kata dasar naem yang secara harfiah berarti to be pleasant atau delightful. ${ }^{17}$ Kata noomi dalam Perjanjian Lama hanya terdapat dalam kitab Rut. Pada ayat 2 kata noomi dijelaskan sebagai isteri Elimelekh akan tetapi pada bagian ini nama itu langsung dihubungkan dengan konteks penderitaan. Carolyn Custis James melihat kehilangan Naomi adalah bencana besar dan penting bagi kitab Rut sebagai konsensus umum bahwa seseorang sedang melihat kisah Ayub versi wanita. ${ }^{18}$ Pada ayat 20 penggunaan kata noomi semakin menguatkan gambaran konteks yang melekat pada ayat 2. Penggunaan kata noomi menampilkan suatu bentuk permainan kata yang 
menjadi menarik dalam kitab Rut, dari noomi berubah menjadi mara. Kata mara berasal dari akar kata marar artinya bitter atau symbolic name of Naomi. Perubahan kata yang dimainkan Naomi terhadap namanya juga sehubungan dengan kenyataan pahit yang dialaminya, sebagaimana dalam penjelasan kata shaar. Naomi menggunakan bentuk kata kerja dari akar kata marar untuk menjelaskan perlakuannya oleh Shaddai, bentuk kata kerja dari marar dapat menggambarkan seseorang yang anaknya telah meninggal. ${ }^{19}$ Kata mara yang terdapat dalam ayat 20 kemudian dapat memunculkan indikasi bahwa Naomi mengeluh kepada Shaddai. Akan tetapi alasan logisnya tepat dijelaskan dalam ayat 21 . Kata mara hanya disebutkan dua kali, selain dalam kitab Rut, juga terdapat dalam Keluaran 15:23 namun mara merujuk kepada nama tempat yang menjadi persinggahan orang Israel untuk meminum air namun airnya pahit, merujuk pada keadaan yang sama dalam kitab Rut yaitu pahit. Dalam konteks Keluaran 15, mara atau pahit menunjukkan kecenderungan bahwa Allah melakukan pengujian terhadap iman orang-orang pilihan-Nya melalui air yang rasanya pahit. ${ }^{20}$ Jika penggunaan kata mara dalam konteks Keluaran merujuk kepada kepahitan sebagai cara pengujian Allah terhadap iman maka hal ini menjadi senada dengan yang ditemukan dalam kitab Rut.

\section{Menafsir Rut 1:1-22}

Berdasarkan pada setting atau latar tempat dari Rut 1:1-22, maka narator membagi tulisannya dalam tiga bagian besar. Bagian pertama dimulai dari 1-7a, bagian kedua 7b-19a dan bagian ketiga ialah 19b-22a. Pada bagian pertama, penulis sebagai narator kitab Rut menempatkan realita penderitaan yang dialami oleh keluarga Naomi. Konteks kelaparan yang terjadi di Israel menunjukkan penderitaan pertama yang terjadi. Menurut Schipper, Rut 1: 1 mewakili satu-satunya kejadian dari konstruksi khusus dalam Alkitab Ibrani, yang menunjukkan suatu jenis aktivitas dari nama pribadi mengikuti "pada zaman." ${ }^{21}$ Schipper menunjuk pada konteks kelaparan sebagai bentuk dari peristiwa yang mengikuti keterangan zaman atau subjek yaitu ketika para hakim yang memerintah. Kelaparan itu terjadi di tanah Betlehem, tempat yang tanahnya subur. Beberapa ahli menyatakan penyebab kelaparan tersebut adalah land-grabbing dari suku Midian dan Amalek (Hak 6:1-6) dan ada kemungkinan disebabkan kekeringan yang berkaitan dengan curah hujan. ${ }^{22}$ Kelaparan menjadi 
sangat mungkin bahkan di tanah yang dianggap berlimpah ruah rotinya. Akan tetapi di dalam teks tidak dijelaskan penyebab dari kelaparan itu, narator hanya mengungkapkannya dengan singkat, mengarah pada indikasi bahwa narator tidak peduli pada faktor penyebab kelaparan, yang penting ialah akibatnya yang kemudian menjadi dasar bagi perkembangan cerita selanjutnya. Keluarga Elimelekh beserta istri dan kedua anaknya berpindah tempat, mereka mengungsi ke Moab (Ay.1-2). Kata noomi muncul sebagai identitas istri Elimelekh.

Dalam ayat 1 terdapat kata lagur dalam versi TB dituliskan sebagai "orang asing, KJV tidak memberikan keterangan tentang lagur ini melainkan hanya menuliskan went to sojourn sedangkan NET menuliskan went to live as a resident foreigner. Sebagai orang asing menunjuk pada keadaan yang tidak memiliki banyak kebebasan atau hak-hak menjadi terbatas. ${ }^{23}$ Terjemahan TB dan NET memberikan kesan yang lebih menampakkan penderitaan keluarga Elimelekh, mereka tidak hanya harus mengungsi melainkan hidup sebagai orang asing di Moab. Bagi Daniel I. Block pilihan Elimelekh merupakan suatu langkah putus asa mengingat permusuhan yang berkepanjangan antara Israel dan Moab, mereka mengira prospek untuk pekerjaan produktif lebih besar. ${ }^{24}$ Perpindahan keluarga Elimelekh ke Moab pada satu sisi menimbulkan kecurigaan dan pandangan bahwa mereka lari dari masalah, bencana dan tidak ingin menyelesaikan bencana itu tanpa meninggalkan Betlehem sehingga yang tampak ialah mereka kehilangan harapan dan memutuskan berpindah ke Moab. Narator tidak terlalu peduli dengan pertanyaan apakah perpindahan itu baik atau buruk, melainkan bertujuan untuk membangun situasi Naomi yang tidak menguntungkan. ${ }^{25}$ Teks tidak menjelaskan secara rinci keputusan Elimelekh sebagai kepala keluarga untuk meninggalkan Betlehem akan tetapi dapat dipahami bahwa narator lebih berfokus dalam menunjukkan penderitaan Naomi.

Di Moab, Naomi kehilangan suami dan anaknya (Ay 3-5). Manaransyah melihat peristiwa kehilangan itu menjadi kepahitan hati, bukan kepahitan hati yang biasa melainkan bagaikan kutuk, yang tidak mudah untuk ditanggungnya. ${ }^{26}$ Kehilangan yang dialami berturut-turut menunjukkan Naomi mengalami penderitaan dan membawa Naomi pada situasi seorang diri, menjadikan Naomi sebagai janda. Tidak ada rincian yang diberikan tentang kematian Elimelekh, karena di satu sisi, tidak ada kesalahan yang dilekatkan pada perilaku Elimelekh, dan di sisi lain, garis 
kepentingan biografis mengarah ke arah lain. ${ }^{27}$ Kehilangan yang dialami Naomi menjadi narasi tersendiri yang tidak dijelaskan oleh narator sebagai indikasi bahwa fokus narator yang jelas ialah Elimlekh meninggalkan Naomi seorang diri. Status dari Naomi dalam dunia orang Yahudi menjadi tidak dianggap karena pertama, Naomi tidak lagi memiliki keturunan langsung dan kedua Naomi menjadi janda di tanah Moab, tempat Naomi sebagai orang asing. Situasi ini memungkinkan Naomi tertekan akibat kehilangan yang terjadi, terlebih dalam konteks Perjanjian Lama mencatat bahwa janda sering kali dimanfaatkan (Yes 10: 2) atau diabaikan dan ditelantarkan (Yes 1:23). ${ }^{28}$ Maka tepatlah kata wattissaer dalam Rut 1 sebagai kehilangan yang sulit untuk diterima, kehilangan yang menimbulkan pertanyaan. Pasalnya kitab Rut tidak menjelaskan penyebab dari kematian suami dan anak-anak Naomi.

Fakta yang meningkatkan kehilangan Naomi adalah bahwa dia perempuan di dunia patriarki sebagai seorang istri dan memiliki anak laki-laki bagi suaminya. ${ }^{29}$ Kata perempuan yang dilekatkan narator pada ayat 3 dan 5 yang merujuk kepada Naomi menggambarkan indikasi lain. Penggunaan kata "perempuan" menunjukkan bagaimana Naomi "dilucuti dari semua identitas" melalui kematian keluarganya dan pada sisi lain menandakan bahwa "kebaikan" ilahi tidak ada dalam ayat $5 .{ }^{30}$ Identitas dan situasi Naomi berubah total, kematian sebagai kehilangan menjadi bencana yang tidak pernah dipikirkan oleh Naomi saat berpindah ke Moab. Dalam Perjanjian Lama, peristiwa yang dialami Naomi juga senada tapi tak sama dengan peristiwa kehilangan yang dialami Ayub.

Kerugian kedua penderita adalah bencana besar. Ayub kehilangan ternak, pembantu, anak-anak, dan kesehatannya. Naomi menanggung kelaparan, nyawa seorang pengungsi, dan kematian suaminya dan kedua putranya (Ayub 1: 13-2: 10; Rut 1: 1-5). Ini adalah kehancuran total bagi kedua penderita, satu-satunya perbedaan adalah bahwa Ayub, sebagai seorang pria dalam budaya patriarki, pada akhirnya dapat memulai kembali. Tidak demikian halnya Naomi, sebagai janda pascamonopause. ${ }^{31}$

Dalam peristiwa yang dialami baik Ayub maupun Naomi kehilangan menjadi realitas yang tidak dapat dipahami, tidak terhindarkan bahkan ada indikasi sebagai ujian iman kepada Ayub maupun Naomi. Akan tetapi lebih baik untuk melihat kehilangan sebagai ujian iman sebab baik Ayub juga Naomi tidak menunjukkan sikap atau faktor melawan perintah Allah, justru Alkitab mencatat mereka sebagai tokoh 
yang saleh, yang taat dan takut kepada Allah. Kehilangan juga menjadi realitas yang dialami oleh Orpa dan Rut karena meninggalnya Mahlon dan Kilyon. Dalam hal ini makna wattissaer tidak hanya berimplikasi secara psikis karena menimbulkan kepahitan hati, akan tetapi juga menimbulkan implikasi sosial budaya dalam memandang kedudukan Naomi di masyarakat. Tidak ada pilihan lagi bagi Naomi selain kembali ke Betlehem (Ay 6-7a).

Bagian kedua 7b-19a menunjukkan rencana kepulangan Naomi yang melibatkan Orpa dan Rut. Dalam perjalanan pulang, Naomi memberikan pilihan kepada Orpa dan Rut untuk kembali ke rumah mereka masing-masing (Ay.8-13). Hal ini menjadi sangat mungkin sebagai pertimbangan logis dari Naomi. Konsekuensi yang harus diterima Naomi dan kedua menantunya menjadi sangat besar, membawa pulang orang Moab dan statusnya ialah sebagai janda. Naomi merasa bahwa tidak masuk akal dan tidak baik untuk mengundang mereka, pada tingkat yang lebih jauh menjadi bagian dari kesulitannya. ${ }^{32}$ Narator menampakkan peran keutamaan dari Naomi sebagai mertua dalam menyikapi kelanjutan hidup dari kedua menantunya. Dalam ayat 9 mulai muncul kata Yahweh sebagai ungkapan berkat Naomi terhadap Orpa dan Rut. Teologi Ibrani Naomi yang sederhana muncul dengan sempurna, Naomi berasumsi bahwa Yahwehnya sendiri memerintah di Moab seperti di Yehuda, dan bahwa semua berkat turun darinya. ${ }^{33}$ Ungkapan Naomi diranasikan oleh narator sebagai harapan untuk berkat, akan tetapi tampak juga seperti ucapan perpisahan kepada Orpa.

Ayat 16 menggambarkan ungkapan kemauan Rut mengikuti Naomi bukan sebagai paksaan tetapi murni dari keinginannya. Kata "Allahmulah Allahku" menampilkan pernyataan lebih kuat dalam pikiran penulis untuk mengalihkan kesetiaan teologis daripada kesetiaan etis. ${ }^{34}$ Perkataan Rut memberikan penekanan khusus dari narator sebagai pernyataan teologis yang menjadi dasar bagi narator meletakkan kesetiaan Rut terhadap Naomi. Kesetiaan itu tidak dibingkai dalam pernyataan kewajiban sebagai menantu mengikuti mertuanya karena Rut telah menikah dengan anak Naomi, melainkan kesetiaan Rut justru berdasar pada argumen teologis dengan menyebut Allah Naomi sebagai Allahnya. Rut siap untuk tidak hanya menerima hal-hal baik dalam hidupnya, tetapi juga dalam hal yang buruk yang dialaminya sebagai konsekuensi dari penyembahannya kepada TUHAN. ${ }^{35}$ Kehilangan 
tidak membuat Rut menjadi gagal paham dengan ungkapan berkat atau harapan Naomi, justru melalui peristiwa kehilangan yang ditekankan narator pada bagian pertama kemudian membentuk pengakuan teologis Rut sebagai wujud kesetiaan menemani Naomi pulang ke Betlehem.

Kepulangan Naomi disambut oleh perempuan-perempuan Betlehem dengan ungkapan "Naomikah itu?". Seperti yang dicatat oleh banyak komentator, Rut tidak berbicara dan tidak diakui pada saat kedatangannya, perempuan penghuni Betlehem memusatkan rasa ingin tahu mereka pada Naomi. ${ }^{36}$ Situasi yang dapat dibayangkan mengarah pada kebingungan atau rasa bertanya-tanya yang muncul dari pemikiran perempuan-perempuan itu, menjadi mungkin karena Naomi tadinya pergi meninggalkan Betlehem kemudian pulang dengan kekosongan, suami dan anakanaknya tidak ada bahkan Naomi justru pulang dengan seorang perempuan yang tidak dikenal. Pada ayat 20-21 Naomi memunculkan permainan kata melalui namanya. Kehilangan yang dialami Naomi membuat pernyataan bahwa namanya pun harus berubah. Naomi pada dasarnya ingin menanggapi pertanyaan perempuan-perempuan itu sambil secara puitis dengan ekspresi secara literal, mengatakan bahwa Naomi memiliki kehidupan yang penuh, tetapi saya kosong."37 Kehidupan yang penuh menyiratkan kesadaran Naomi pada keadaan dulu ketika dia meninggalkan Betlehem, masih memiliki suami, anak dan persiapan untuk hidup di Moab akan tetapi kehilangan semua itu menjadikan kehidupan Naomi menjadi kosong, segala sesuatu yang membuatnya hidup telah hilang. Kata mara muncul pada ayat 20 sebagai bentuk respons Naomi terhadap kehilangan, perubahan nama dari Naomi. Satu sisi menandakan kemakmuran sedangkan yang satu menandakan kesedihan. ${ }^{38}$ Ungkapan Naomi digunakan oleh narator untuk menutup rangkaian peristiwa yang terjadi begitu cepat kepada Naomi.

Ayat 21 menampilkan kesadaran Naomi terhadap adanya kehadiran Tuhan dibalik peristiwa kehilangan yang terjadi. Penegasannya tentang peran Tuhan mungkin membuat pembaca modern tidak nyaman, seperti halnya pengetahuan pembaca tentang peran Tuhan dalam kehilangan Ayub (Ayub 1-2). ${ }^{39}$ Peristiwa kehilangan yang dialami Naomi direspons dengan keluhan, marah dan mempertanyakan kehilangan. Naomi tidak menggugat Allah atau menuduh Allah, melainkan lebih kepada pengakuan akan kehilangan sebagai bentuk kemahakuasaan 
Tuhan dalam hidup. Narator Rut tidak memberi petunjuk tentang keputusan apa pun yang dibuat di surga, dalam keluhan Naomi tersirat tentang Tuhan adalah keyakinannya akan kedaulatan dan kekuasaannya. ${ }^{40}$ Ketiadaan penjelasan dari narator terhadap alasan dibalik kehilangan Naomi bahwa apakah kehendak Tuhan atau tidak menunjukkan bahwa narator tidak berfokus pada karakter Naomi dalam hubungannya dengan Tuhan, melainkan fokus utama dari narator ialah kehilangan, peristiwa kekosongan Naomi sebagai pengaturan utama terhadap narasi yang dibangun oleh narator dalam kitab Rut. Masalah kekosongan Naomi adalah penggerak narasi. ${ }^{41}$ Dalam hal ini dapat dipahami bahwa konteks kehilangan yang menyebabkan Naomi menderita, menjadikan Naomi sebagai janda, bahkan dia harus kembali dalam keadaan kosong ke tanah Betlehem dan keluhan Naomi kepada Tuhan merupakan gambaran utama dari narator kitab Rut. Jadi dapat dilihat bahwa konteks kehilangan Naomi menyiratkan makna teologis yaitu Tuhan berdaulat atas hidupnya sekaligus memuat ajakan pastoral bahwa kehilangan itu perlu diakui dan mengeluh menjadi cara yang wajar dalam merespons realitas kehidupan.

\section{KESIMPULAN}

Pada bagian ini penulis menemukan bahwa dalam Rut 1:1-22 sebuah narasi kehilangan Naomi sebagai kemalangan, kekosongan, dan penderitaan. Dari respons yang ditunjukkan Naomi, responsnya ialah mengeluh kepada Allah karena peristiwa kehilangan yang mereka alami tetapi dibalik itu mereka tetap mengakui kehadiran Allah dalam masa kemalangan, penderitaan yang dialami. Berdasarkan pada pertanyaan di awal bahwa apakah Naomi menunjukkan respons menggugat Allah atas kehilangan yang terjadi? Jawabannya ialah tidak, penulis justru melihat Naomi menerima kehilangan itu

\section{Endnotes:}

1 Douglas Stuart, Old Testament Exegesis: A Handbook for Students and Pastors (Louisville: Westminster John Knox Press, 2009), 25.

${ }^{2}$ Yonky Karman, Bunga Rampai Teologi Perjanjian Lama: Dari Kanon Sampai Doa (Jakarta: BPK Gunung Mulia, 2007), 13.

${ }^{3}$ Lembaga Alkitab Indonesia, Alkitab Edisi Studi (Jakarta: Percetakan Lembaga Alkitab Indonesia, $2015), 423$. 
${ }^{4}$ Florence Farida, "Tidak Ada Yang Terjadi Dalam Kehidupan Orang Percaya Karena Kebetulan," dalam Prosiding Seminar Teologi Kitab Rut, ed. oleh Peniel C.D Maiaweng (Makassar: Sekolah Tinggi Theologia Jaffray, 2016), 3.

${ }^{5}$ Eben Nuban Timo, Penebusku Ada Di Betlehem: Kumpulan Khotbah Dari Kitab Rut (Jakarta: BPK Gunung Mulia, 2006), 2.

${ }^{6}$ Jeremy Schipper, Ruth: A New Translation with Introduction and Commentary (Haven: Yale University Press, 2016), 18.

${ }^{7}$ James McKeown, Ruth (Grand Rapids: William B. Eerdmans Publishing Company, 2015), 2.

${ }^{8}$ Bruce K Waltke dan Charles Yu, An Old Testament Theology: An Exegetical, Canonical, and Thematic Approach (Grand Rapids: Zondervan, 2007), 850.

${ }^{9}$ Schipper, Ruth: A New Translation with Introduction and Commentary, 17.

${ }^{10}$ Schipper, 18.

${ }^{11}$ Alicia Ostriker, "The Book of Ruth and The Love of The Land," Biblical Interpretation 10, no. 4 (2002): 345 .

12 "Arti kata cerita - Kamus Besar Bahasa Indonesia (KBBI) Online," diakses 9 Desember, https://kbbi.web.id/cerita.

${ }^{13}$ Tod Linafelt, "Narrative and Poetic Art in The Book of Ruth," Interpretation: A Journal of Bible and Theology 64, no. 2 (April 2010): 123.

${ }^{14}$ Linafelt, 127.

${ }^{15}$ Schipper, Ruth, 28.

16 "Ruth 1:5 Commentaries: Then both Mahlon and Chilion also died, and the woman was bereft of her two children and her husband.," diakses 29 November 2021, https://biblehub.com/commentaries/ruth/1 5.htm.

17 "Strong's Hebrew: 5276. נָָעֵ (naem) -- to be pleasant, delightful, or lovely," diakses 29 November 2021, https://biblehub.com/hebrew/5276.htm.

${ }^{18}$ Carolyn Custis James, Finding God in The Margins: The Book of Ruth (Bellingham: Lexham Press, 2018), 6 .

${ }^{19}$ Schipper, Ruth, 35.

${ }^{20}$ Awasuning Manaransyah, "Tuhan Mengubah Mara Menjadi Matov: Kitab Rut," Missio Ecclesiae, Tuhan Mengubah Mara Menjadi Matov, 6, no. 2 (Oktober 2017): 112.

${ }^{21}$ Schipper, Ruth, 11.

22 Marsi Bombongan Rantesalu dan Nelci Nafalia Ndolu, "Makna Tanah Leluhur Bagi Naomi Berdasarkan Rut 1:1-22," JIREH- Jurnal Ilmiah Religiosity Entity Humanity 1, no. 1 (Juni 2019): 90.

${ }^{23}$ Manaransyah, "Tuhan Mengubah Mara Menjadi Matov: Kitab Rut," 91.

${ }^{24}$ Daniel I Block, "Ruth and Work," Theology of Work Project 23 (Mei 2013): 2.

25 Jason Driesbach, "Ruth," dalam Cornerstone Biblical Commentary, ed. oleh Philip W. Comfort Comfort, vol. 3 (Carol Stream: Tyndale House Publishers, 2012).

${ }^{26}$ Awasuning Manaransyah, "Tuhan Mengubah Mara Menjadi Matov: Kitab Rut," Missio Ecclesiae 6(2) (Oktober 2017): 117.

27 Biblehub, "Pulpit Commentary," https://biblehub.com/commentaries/ruth/1-3.htm (diakses 13 Desember 2020)

28 Jason Driesbach, "Ruth," dalam Cornerstone Biblical Commentary Volume 3, peny. Philip W. Comfort (Carol Stream: Tyndale House Publishers, 2012).

${ }^{29}$ James, Finding God in The Margins, 19.

${ }^{30}$ Schipper, Ruth, 24.

31 James, Finding God in The Margins, 6.

32 "Ruth 1:8 Commentaries: And Naomi said to her two daughters-in-law, "Go, return each of you to her mother's house. May the LORD deal kindly with you as you have dealt with the dead and with me.," diakses 29 November 2021, https://biblehub.com/commentaries/ruth/1-8.htm.

33 "Ruth 1:8 Commentaries."

${ }^{34}$ Linafelt, "Narrative and Poetic Art in The Book of Ruth," 125.

${ }^{35}$ Christina Ukung dan Peniel C. D Maiaweng, "Apakah Rut, Perempuan Moab Adalah Penyembah TUHAN?,” Jurnal Jaffray 16, no. 2 (Oktober 2018): 167.

${ }^{36}$ Schipper, Ruth, 28.

${ }^{37}$ Driesbach, "Ruth." 


\footnotetext{
38 "Ruth 1:20 Commentaries: She said to them, "Do not call me Naomi; call me Mara, for the Almighty has dealt very bitterly with me.," diakses 13 Desember 2020, https://biblehub.com/commentaries/ruth/1-20.htm.

${ }^{39}$ Driesbach, "Ruth."

${ }^{40}$ Driesbach.

${ }^{41}$ Driesbach.
}

\section{DAFTAR PUSTAKA}

“Arti kata cerita - Kamus Besar Bahasa Indonesia (KBBI) Online." Diakses 29 November 2021. https://kbbi.web.id/cerita.

Block, Daniel I. “Ruth and Work.” Theology of Work Project 23 (Mei 2013): 1-15.

Driesbach, Jason. "Ruth." Dalam Cornerstone Biblical Commentary, disunting oleh Philip W. Comfort Comfort, Vol. 3. Carol Stream: Tyndale House Publishers, 2012.

Farida, Florence. "Tidak Ada Yang Terjadi Dalam Kehidupan Orang Percaya Karena Kebetulan." Dalam Prosiding Seminar Teologi Kitab Rut, disunting oleh Peniel C.D Maiaweng. Makassar: Sekolah Tinggi Theologia Jaffray, 2016.

James, Carolyn Custis. Finding God in The Margins: The Book of Ruth. Bellingham: Lexham Press, 2018.

Karman, Yonky. Bunga Rampai Teologi Perjanjian Lama: Dari Kanon Sampai Doa. Jakarta: BPK Gunung Mulia, 2007.

Lembaga Alkitab Indonesia. Alkitab Edisi Studi. Jakarta: Percetakan Lembaga Alkitab Indonesia, 2015.

Linafelt, Tod. "Narrative and Poetic Art in The Book of Ruth." Interpretation: A Journal of Bible and Theology 64, no. 2 (April 2010): 117-29.

Manaransyah, Awasuning. "Tuhan Mengubah Mara Menjadi Matov: Kitab Rut." Missio Ecclesiae, Tuhan Mengubah Mara Menjadi Matov, 6, no. 2 (Oktober 2017): 112-27.

McKeown, James. Ruth. Grand Rapids: William B. Eerdmans Publishing Company, 2015.

Ostriker, Alicia. "The Book of Ruth and The Love of The Land." Biblical Interpretation 10, no. 4 (2002): 343-59. 
Rantesalu, Marsi Bombongan, dan Nelci Nafalia Ndolu. "Makna Tanah Leluhur Bagi Naomi Berdasarkan Rut 1:1-22.” JIREH- Jurnal Ilmiah Religiosity Entity Humanity 1, no. 1 (Juni 2019): 87-98.

"Ruth 1:5 Commentaries: Then both Mahlon and Chilion also died, and the woman was bereft of her two children and her husband." Diakses 29 November 2021. https://biblehub.com/commentaries/ruth/1-5.htm.

"Ruth 1:8 Commentaries: And Naomi said to her two daughters-in-law, "Go, return each of you to her mother's house. May the LORD deal kindly with you as you have dealt with the dead and with me." Diakses 29 November 2021. https://biblehub.com/commentaries/ruth/1-8.htm.

"Ruth 1:20 Commentaries: She said to them, "Do not call me Naomi; call me Mara, for the Almighty has dealt very bitterly with me." Diakses 29 November 2021. https://biblehub.com/commentaries/ruth/1-20.htm.

Schipper, Jeremy. Ruth: A New Translation with Introduction and Commentary. Haven: Yale University Press, 2016.

“Strong's Hebrew: 5276. נוָעָם (naem) -- to be pleasant, delightful, or lovely." Diakses 29 November 2021. https://biblehub.com/hebrew/5276.htm.

Stuart, Douglas. Old Testament Exegesis: A Handbook for Students and Pastors. Louisville: Westminster John Knox Press, 2009.

Timo, Eben Nuban. Penebusku Ada Di Betlehem: Kumpulan Khotbah Dari Kitab Rut. Jakarta: BPK Gunung Mulia, 2006.

Ukung, Christina, dan Peniel C. D Maiaweng. "Apakah Rut, Perempuan Moab Adalah Penyembah TUHAN?” Jurnal Jaffray 16, no. 2 (Oktober 2018): 162-74.

Waltke, Bruce K, dan Charles Yu. An Old Testament Theology: An Exegetical, Canonical, and Thematic Approach. Grand Rapids: Zondervan, 2007. 